\title{
Studying Effect of Customer Relationship Management (CRM) System on Attracting Customer Satisfaction Case Study: Teacher Insurance Company in Isfahan Province
}

Dr. Javad Mehrabi

Department of Public Management, Qazvin Branch, Islamic Azad University, Qazvin, Iran

Dr. Mohammad Hossein Mosharaf Javadi

Faculty Member, department of business administration, University of Isfahan, Iran

Mohammad Hasan Tanhaei

Department of Management\&Accounting, Qazvin Branch, Islamic Azad University, Qazvin, Iran

\section{Batool Samangoei}

Graduate Student of Business Administration Payame- Nour University, Tehran, Shahre Ray unit, and Educational Services Expert in University of Isfahan, Iran

Accepted: December 26, 2011 Published: February 3, 2012

Doi:10.5296/ijld.v2i1.1355 URL: http://dx.doi.org/10.5296/ijld.v2i1.1355

\begin{abstract}
Background: the present survey was conducted to determine "effect of customer relationship management system on attracting customer satisfaction with regard to teacher insurance company in Isfahan province".

Methodology: This survey was conducted using descriptive-field study. Statistical population of the present survey included all of the customers of teacher insurance comany in Isfahan province in which cluster random sampling method was used. The sample volume was
\end{abstract}


estimated equal to 185 persons. Data analysis has been done through SPSS software and statistical tests such as: one-variable $t$, independent $t$, one-sided variance analysis and Hoteling $\mathrm{t}^{2}$.

Findings: Research results revealed that customers' satisfaction was more than average level in terms of all four-fold factors (four standards to be measured) including manner of responding, quality of services, and electronic services and it is at the average level about cost of services. Conclusion: this private company has been able to implement this system through developing of its skills and proficiencies in the field of offering services effectively. This issue is due to paying attention to customers and establishment of personal relations with them in order to provide their needs and desires.

Key words: Customer, Customer Relationship Management, Services, Quality of Services

\section{Introduction}

Human beings' life cycle and life flow of economic, social and cultural activities of societies are full of different kinds of risks and threats. In fact insurance is a contract by which one party guarantees to compensate the loss or pay a certain fund in lieu of paying the fund or funds from the other party if an incident occurs.

Insurance companies are one of the dynamic and important institutions in many countries. Paying attention to characteristics and advantages that such companies have for the society is very important. These companies create social welfare and peacefulness in the society by transmission of risk from people to themselves (Gholamian et al, 2007).

The considerable point in an insurance industry is that development of this industry is more difficult than other economic sectors, as the insurance premium that the insured person pays won't necessarily be leaded to receiving the loss and often he may never receive any payment with regard to his paid insurance premiums. Thus, the need for purchasing insurance converages in an individual is revived harder and later compasedwith purchasing of other products and services.

Also, increasing number of insurance companies across the world cause them to try to have more shares in the market and look for customer satisfaction and finally customer loyalty. Customers that are satisfied with the organization, transfer their positive feelings and preferences to others and thus they become an advertising tool for the organization. As a result customer attraction cost and fees are decreased (Aali, 2003).

\section{Research questions:}

QuestionA): Are customers satisfied with responsiveness manner of agencies of teacher insurance company?

QuestionB): Are customers satisfied with quality of services in agencies of teacher insurance company?

QuestionC): Are customers satisfied with cost of services in agencies of teacher insurance company? 
QuestionD) : Are customers satisfied with electronic services in agencies of teacher insurance company?

\section{Theoretical Framework}

\section{Services \& Service Quality}

Services include intangible duties that satisfy the needs of consumers or commercial users. In other words, services and products can be assumed on two ends of a continuum, as most cases are a combination of these two features (Nasehifar \& Haghbayan, 2009). Most authors have pointed out five fundamental principles that distinguish service activities from non-service ones. These five principles include: intangibility, instability, heterogeneity, inseparability and non-posessiveness of the services (Mousavi \& Rezaeian, 2007). Here, it needs to be pointed out that a complaining customer is not an enemy to the organization. Those customers who complain about specifications of a product or the services provided by the company are more likely to come back, as compared to those customers who never express any complain about the organization. That is to say an appropriate response to the complaining customers will make them $50 \%$ faithful to the organization; otherwise, they will go to the rivals (Behin Moshaveran Atiyehsaz Conference, 2006). Thus complaints should be addressed as opportunities to improve relationships with the customers. They should be used as instruments for satisfying the changeable demands of the customers (ranjbaran et al, 2002). The studies show that only $10 \%$ of the personnel in the industrial sectors are directly in contact with the customers. However, this increases to $90 \%$ or even $100 \%$ for the service-providers (Nasehifar \& Haghbayan, 2009).

Researchers and scientists in service marketing have presented several metaphors for service quality. For example, Berry has defined it as "the most powerful competitive weapon", Clave has considered it as "the reviving blood for the organization" and Peters as "the magic bullet that provides the customer with less expensive services at lower prices" (Haghighi et al, 2003). The customers expect two desirable and sufficient levels of services that are separated by the tolerance zone of the customer (Baglou \& Zomorodpoush, 2009). Tangibles include the products or protections and supports received from the products and services. However, Tangibles dimensions are less observable in governmental and service-providing organizations such as universities and higher education institutes and the customers of organizations such as universities evaluate the tangibles based on the availability of instructional credits. Interactive quality refers to the relation between the customer and the service-provider and organizational quality refers to the general conceptions from organization (Shahriari, 2006).

Generally, most definitions of quality are customer-oriented when they are being used about quality. In other words, quality assessment in the service-providing sector is carried out based on the customer's conception (Samavi et al, 2008).

The knowledge of the concept of service quality and the attempt to improve it has resulted in providing high-quality services, and improving the satisfaction of students can be expected as a result of improving the service quality. Then, the service quality is defined as a scale for evaluating the customers' satisfaction. 


\section{Customer Satisfaction}

Several definitions have been offered for customer satisfaction by marketing theoreticians. Cutler defines customer satisfaction as the degree to which the real performance of a company satisfies the expectations of customers. To Cutler, if the performance of a company satisfies the expectations of the customers, the customer will feel satisfied, otherwise, the customer will be dissatisfied (Divandari \& Delkhah, 2005; 188).

Jamal and Naser (2002) define customer satisfaction as the feeling or attitude of a customer toward a product or service after using them. Blanchard and Galloway believe: Customer satisfaction results from the conception of the customer within a value-based relation or transaction, so that price equals the proportion of the quality of offered services to the prices and expenses paid by the customer (Hallowell, 1996; 28). Kotler defines satisfaction as the degree that actual performance of a company satisfies customer expectations. According to him if performance of a company satisfies customer expectations, the customer will have sense of satisfaction; otherwise he will be dissatisfied (Abdoli \& Fereidunfar, 2008).

\section{Customer Relationship Management}

CRM was first used in a general sense by Management teachers such as Peter Drucker and Theodore Levitt in 1960s (Ghanbari, 2006). Customer Relationship Management includes individuals, processes and technology and it is seeking for the customers' conception of an organization. CRM is a combined approach for managing the relationships while focusing on keeping customers and improving relationships with them (Sharafoddin, 2010).

Customer relationship management is not a new concept in marketing, rather it has been established based on three aspects of marketing management that are customer orientation, relations of the marketer and marketing information banks (Mahdavinia, Ghodratpour 2006). Customer relationship management gives a clear picture along with all required details from the customers and provides the possibility to make a special and efficient relationship with each customer in order to lose no opportunity for more sales and providing customers' satisfaction (Maleki \& Darabi, 2010).

\section{Research methodology}

Statistical population of this survey included all customers of a company teacher insurance company in Isfahan province. The required sample volume was estimated equal to 185 persons showed in the following formula. First thirty (30) questionnaires were distributed among the customers and then calculating formula:

$$
\mathrm{n}=\frac{t^{2} p q}{d^{2}} \quad \mathrm{n}=\frac{(1.96)^{2} \times 0.86 \times 0.14}{(0.05)^{2}}=185
$$

Cronbach alpha coefficient was (0.92) . Cluster random sampling method was used. Cluster sampling is "choosing of the analysis unit and in other words major unit of studying during several continuous sampling phases" (maleki\&darabi,2010). Consequently, Isfahan province was divided into five regions as followed. then a number of agencies were selected randomly from each region and questionnaires were distributed among the customers of such agencies. Questionnaire is the tool of data collection that its validity has been confirmed by proficient 


\section{Ml Macrothink}

International Journal of Learning \& Development

ISSN 2164-4063

2012, Vol. 2, No. 1

experts. Data analysis has been done through SPSS software \& statistical tests such as one-variable $t$, independent $t$, one-sided variance analysis and Hoteling $t^{2}$. In this research the theoretical framework has been selected from several models which all dealt with customer satisfaction.

Table 1- division of statistical population into clusters and selecting the proposed clusters

\begin{tabular}{|l|l|l|l|}
\hline $\begin{array}{l}\text { Dividing Isfahan } \\
\text { province }\end{array}$ & $\begin{array}{l}\text { Number of } \\
\text { agencies in each } \\
\text { region }\end{array}$ & $\begin{array}{l}\text { Number of selected } \\
\text { agencies in each } \\
\text { region }\end{array}$ & $\begin{array}{l}\text { Number of distributed } \\
\text { questionnaires in each } \\
\text { region }\end{array}$ \\
\hline North West & 19 & 9 & $54+1$ \\
\hline North East & 10 & 3 & $18+1$ \\
\hline Center & 12 & 6 & $36+1$ \\
\hline Southwest & 20 & 9 & $54+1$ \\
\hline Southeast & 11 & 3 & $18+1$ \\
\hline Sum & 72 & 30 & $180+5=185$ \\
\hline
\end{tabular}

Testing conformity of research questions with standard score (supposed average 3):

QuestionA) Are customers satisfied with responsiveness manner of agencies of teacher insurance company?

Table 2- comparing the average score of customers' satisfaction from the manner of responsiveness in view of the customers

\begin{tabular}{rcccccc}
\hline & Mean & $\begin{array}{c}\text { Standard } \\
\text { error }\end{array}$ & Sd & t & Df \\
\hline $\begin{array}{r}\text { responsiveness } \\
\text { manner }\end{array}$ & 3.8 & & 0.062 & 0.531 & 12.90 & 184 \\
\hline
\end{tabular}

According to results of table 2, the observed $t$ is larger than the critical amount of table at error level \%5. Therefore, amount of customers' satisfaction from responsiveness manner of agencies of teacher insurance company in view of customers is more than the average level.

QuestionB) Are customers satisfied with quality of services in agencies of teacher insurance company?

Table 3- comparing the average score of customers' satisfaction from services quality in view of customers

\begin{tabular}{rrrrrrr}
\hline & Mean & Standard error & sd & T & Df \\
\hline $\begin{array}{c}\text { Services } \\
\text { quality }\end{array}$ & 4.10 & 0.4 & 0.05 & 22.02 & & 184 \\
\hline
\end{tabular}

According to results of table3, the observed $t$ is larger than the critical amount of table at error level \%5. Therefore, amount of customers' satisfaction from services quality of agencies of teacher insurance company in view of customers is more than the average level.

QuestionC) Are customers satisfied with cost of services in agencies of teacher insurance company?

Table4- comparing the average score of customers' satisfaction from services quality in view of customers

\begin{tabular}{lllll} 
Mean & Standard error & sd & T & Df \\
\hline
\end{tabular}




\begin{tabular}{rlllll}
\hline $\begin{array}{r}\text { Services } \\
\text { cost }\end{array}$ & 3.10 & 0.66 & 0.059 & 1.69 & 184 \\
\hline
\end{tabular}

According to results of table 3 , the observed $t$ is moderate the critical amount of table at error level \%5. Therefore, amount of customers' satisfaction from services cost of agencies of teacher insurance company in view of customers is moderate the average level.

QuestionD) Are customers satisfied with electronic services in agencies of teacher insurance company?

Table5- comparing the average score of customers' satisfaction from Electronic Services in view of customers

\begin{tabular}{lrrrrrr}
\hline & Mean & Standard error & Sd & T & Df \\
\hline $\begin{array}{l}\text { Electronic } \\
\text { Services }\end{array}$ & 3.91 & 0.541 & 0.061 & 14.91 & & 184 \\
\hline
\end{tabular}

According to results of table3, the observed $t$ is larger than the critical amount of table at error level \%5. Therefore, amount of customers' satisfaction from Electronic Services of agencies of teacher insurance company in view of customers is more than the average level.

\section{Comparing average amount of factors related to customers}

Table 6- comparing average score of customer relationship management system in view of customers

\begin{tabular}{|l|l|l|}
\hline & Average & Standard deviation \\
\hline manner of responsiveness & 3.8 & 0.531 \\
\hline Quality of services & 4.10 & 0.40 \\
\hline Cost of services & 3.1 & 0.66 \\
\hline Electronic services & 3.91 & 0.541 \\
\hline
\end{tabular}

$$
\mathrm{t}^{2}=151.19 \quad \mathrm{~F}=51.54 \quad \mathrm{sig}=0.001
$$

Results of table 6 show that the observed $F$ is significant at level $p \leq 0.05$, therefore there is difference between customers' satisfaction level from studying dimensions in view of customers. The highest amount is related to quality of services and the lowest amount is related to cost of services.

\section{Results of the survey}

Responsiveness results demonstrated that customers' satisfaction has been more than average level and this is resulted from factors such as physical condition of the environment, permanent presence of employees, lawfulness, transparency of responsiveness manner, responsibility and observance of civility and respect towards customers.

Quality of services result illustrate that customers' satisfaction has been more than average level and this is resulted from high security level of customers' information by the insurance, timely action to eliminate customers' problems, existence of diversity in offering kinds of insurance, proficiency level of employees with regard to affairs and insurance rules and issue of insurance policies with out any defect. 


\section{Macrothink

Cost of services results revealed that customers' satisfaction from cost of services of teacher insurance in Isfahan province has been around the average level. Hence we can conclude that this company should try more to attract customers' satisfaction in order to improve the manner of payments, acceleration in payment time, reduction of costs and the spenting time to receive services.

Electronic services results indicate that customers' satisfaction from such services has been more than average level. Satisfaction more than average level is resulted from factors such as having customer data base, sufficiency of telephone for responsiveness, existence of talking telephone to transfer information and receive services, existence of informatics website and up to dating issue.

Customers' satisfaction from customer relationship management system in teacher insurance showed that this private company has been able to implement this system through developing its skills and proficiencies in the field of offering services effectively. This is due to paying attention to customers and establishment of personal relations with them in order to provide their needs and desires. 


\section{References}

Aali, S (2003), Customer satisfaction, Tadbir Monthly Magazine, 130: 12-20

Abdoli, K; Fereidunfar, S (2008), Customer satisfaction models, Tadbir Monthly

Magazine, 182

Baglou, R.; Zomorrodpoush, F. (2009) Specifying the Position of Customers Relationship Management in Libraries and Information Centers, Librarianship \& Information Quarterly, No. 47

Gholamian, M; Khaje Afzali, M; Ebrahimi, B (2007), Knowledge management in relation to customer, Tadbir Monthly Magazine, 178: 20-26

Haghighi, M.; Moghimi, M; Keimasi, M. (2003) Service Loyalty: The Effects of Service Quality and the Mediating Role of Customer Satisfaction, Management Science, No. 60-61: 53-72

Hallowell R., (1996); The relationship of customer satisfaction, customer loyalty and profitability: an empirical study, International Journal Service

Ranjbarian B.; Rashidkaboli, M.; Haghshenas, A.; Yavari, Z. (2002) The Study of

Customer Satisfaction with After-Sale Services Quality; Case Study: Xerox Co. in sfahan Province, Commercial Research Quarterly, No. 25: pp. 127-145

Samavi, H.; rezaeimoghaddam, K.; Baradarn, M. (2008) Customer-Oriented Activities and Their Application in Higher Education System; Case Study: Higher Education on Agriculture in Khuzestan Province, Research \& Planning in Higher Education Quarterly, No. 143: pp. 121-49

Behin Moshaveran Atiyehsaz Modiriyat Co. (2006) Measuring Customers Satisfaction: Viva the Complaining Customer, Behin Moshaveran Atiyehsaz

Maleki, A; Darabi, M (2010), Different frameworks of implementing customer relationship management, Automobile Industry Monthly Magazine, 130

Mahdavinia, M; Ghodratpour, B (2006), Function of customer relationship management in retaining and increasing of customers of the insurance company, Automobile Industry Monthly Magazine, 77: 45-60

Shahriyari, S. (2006) The Effects of Customer Orientation Policies of Agri Bank based on Respect for Customer Plan on customer Satisfaction in Shiraz, MA Thesis, Faculty of Graduate Studies - Khorasgan University

Mousavi, F.; Rezaeian, S. (2007) The Role of Electronic Customer Relationship (e- CRM)in Tourism in Iran, Modiriyat Farda, No. 13-14

Nasehifar, V.; Haghbayan, A. (2009) Payment System Quality in Mellat Insurance

Company According to the Customers and Presenting Some Strategies for Improving it for Auto Insurance, Insurance Industry Quarterly, No. 89-90: pp. $23-45$

Venoos, D.; Madadiyekta, Sh. (2005) The Study of Factors Affecting Customer

Satisfaction with Internal Flights of IRI Airline (Homa), Administrative Sciences \& Economics: University of Isfahan 